\title{
Determinants of Early Life Leptin Levels and Later Life Degenerative Outcomes
}

\author{
Delia-Marina Alexe, MD; Garyfallia Syridou, MD; and Eleni Th. Petridou, MD, MPH
}

\begin{abstract}
The early (intrauterine and neonatal) life environment plays an important role in programming the susceptibility in later life to chronic degenerative diseases, such as obesity, cardiovascular diseases, diabetes mellitus, cancer and osteoporosis. Among other hormones, leptin plays a major role in the regulation of the overall metabolism and has multiple neuroendocrine (adeno- and neuro-hypophysis axes and the hypothalamus-pituitary-adrenal axis) and immune functions. The hormone exerts its actions beginning in the early life time period, regulating the intrauterine and early extrauterine life growth and development, as well as the adaptation to extrauterine life, neonatal thermogenesis and response to stress. Recent findings also support a role of leptin in the process of fetal bone remodeling and brain development. Therefore, it is of interest to explore the physiology of leptin in early life, as well as those factors that may perturb the balance of the hormone with pathological consequences in terms of confining an increased risk for disease in later life. This review aims to summarize reported findings concerning the role of leptin in early life, as well as the association of fetal, maternal and placental factors with leptin levels, while attempting to speculate mechanisms through which these factors may influence the risk for developing chronic diseases in later life.
\end{abstract}

Keywords: Degenerative health outcomes; Early life; Later life; Leptin

I

ntrauterine factors are important determinants of weight at birth, whereas a poor intrauterine milieu may program an increased susceptibility and, eventually, risk for developing chronic degenerative diseases in later life, such as obesity, hypertension, other cardiovascular diseases, type- 2 diabetes mellitus and osteoporosis. ${ }^{1-6}$ With regards to carcinogenesis, in particular breast cancer, the association of fetal hormone levels with the stem cell potential has pointed to the early life roots of the disease in the sense that a highly estrogenic intrauterine environment may represent a 'fertile soil' for carcinogenesis in the breast tissue. ${ }^{7}$ Apart from pregnancy estrogens, there has been an increasing interest in exploring the potential role of other components of the intrauterine and infantile hormonal environment in the causation of chronic diseases in later life, and leptin is a strong candidate among them.

Leptin, the product of the obesity $(o b)$ gene, was discovered relatively recently (1994) and is a hormone of $16 \mathrm{kDa}$ comprising 167 amino acids. ${ }^{8}$ The central source of leptin is the adipose tissue (white and brown), although it can be also produced in other sites, including the placenta. ${ }^{9}$

Reprint Requests: Eleni Th. Petridou, MD, MPH, Professor of Epidemiology and Preventive Medicine, Department of Hygiene and Epidemiology, Athens University School of Medicine, 75 M. Asias Street, Goudi, II527, Athens, Greece, Email: epetrid@med.uoa.gr
Leptin plays an essential role in the regulation of energy homeostasis, food intake and body composition beginning in the early life, when the hormone also controls overall fetal growth and development. ${ }^{9}$ At the central nervous system (CNS) level, leptin exerts neurotrophic actions that control feeding during the critical period of development of the hypothalamus. Unlike what happens in later life, some findings from animal studies indicate that leptin does not inhibit the appetite during intrauterine and early postnatal life. On the contrary, it seems that leptin promotes swallowing activity and hyperphagia, therefore contributing to the rapid growth and weight gain of the newborn, but this evidence is still inconclusive. ${ }^{10,11}$ Thus, factors that influence fetal leptin levels may alter the programming of the appetite behavior by modifying the normal set-points, as well as the energy metabolism and adiposity. These changes further lead to an increased risk of developing cardiovascular and metabolic diseases in later life. 10,12,13

Children suffering from leptin deficiency due to a rare leptin gene mutation develop morbid obesity in early childhood, have no pubertal development and have important

\footnotetext{
Received: February 2I, 2006 Revised: July 25, 2006 Accepted:August 29, 2006

Financial Disclosure: The project is co-funded by the European Social Fund and National Resources - (EPEAEK II) PYTHAGORAS.
} 
dysfunctions of growth and thyroid hormones. ${ }^{14}$ Neonates that have either high leptin levels at birth (e.g., offspring of mothers with gestational diabetes) ${ }^{15,16}$ or low leptin levels (e.g., small for gestational age infants) ${ }^{17}$ have a higher risk of developing obesity and type 2 diabetes mellitus compared with children who have normal leptin levels at birth. ${ }^{18}$

Furthermore, some evidence from experimental studies supports the involvement of leptin in the formation of mammary glands, whereas both physiological and pathological breast cells express leptin. ${ }^{19-21}$ Therefore, an adverse intrauterine environment that modifies leptin levels may perturb the reproductive path and increase the risk of breast cancer in adult life. Lastly, there is accumulating evidence that the risk of osteoporosis may also be determined by factors acting on the bone development during the intrauterine and infant life via the alterations in leptin dynamics. 22,23

Given the importance of fetal adipose tissue and its hormones, including leptin, in terms of fetal growth and maturation for both survival at birth and overall health, we present a review of published evidence related to the role of leptin in early life physiology, specifically in relation to the reproductive function overall, energy homeostasis, infant growth, brain development and fetal bone remodeling. Moreover, an effort is made to summarize reports on the influence of fetal, maternal and placental factors in defining leptin levels with special focus on how these variables may affect the pathological risk in later life.

\section{MULTIPLE ROLES OF LEPTIN IN HUMAN PHYSIOLOGY}

\section{Leptin in Relation to Energy Homeostasis}

In adults, leptin regulates overall metabolism, including food intake, energy balance and body temperature by signaling satiety and decreasing the sensation of hunger at the hypothalamic level. ${ }^{24}$ At the peripheral level, the hormone stimulates the process of oxidation of fatty acids in muscles, inhibits the accumulation of triglycerides in hepatic cells, ${ }^{25}$ and has potent lipid-lowering effects in peripheral tissues and plasma that are thought to be essential for the prevention of cellular lipotoxicity and insulin resistance. ${ }^{26}$

Basic functions of the organism, such as thirst and hunger-mediated ingestive behavior, are programmed in utero, and leptin seems to be an essential regulator in this process through its neurotrophic actions at the hypothalamic level. ${ }^{10,12,13}$ There is some evidence from experimental studies, however debatable, that in early neonatal life, leptin may promote hyperphagia as an adaptive response to overcome the physiological weight loss observed during postnatal days ${ }^{10,11}$ and may also be a signal that initiates the enteric feeding. ${ }^{26}$ The full extent of the involvement of this hormone in the regulation of these functions, however, has not been clarified.
Leptin in Relation to Growth and Development of the Fetus and the Infant

Different growth patterns in utero are accompanied by specific changes in leptin levels. ${ }^{27}$ For instance, small for gestational age infants have lower leptin levels at birth than appropriate for gestational age children. On the contrary, large for gestational age neonates have higher leptin levels. ${ }^{17,18}$ Thus, leptin may be an important factor for growth and development of the fetus, whereas its effects seem independent of insulin and the growth hormone insulin-like growth factor-I system. ${ }^{9}$

Recent studies suggest the implication of leptin in the regulation of some mitochondrial proteins, such as the uncoupling protein-1, specific to brown adipose tissue and critically important for the initiation of non-shivering thermogenesis of the newborn and during the transition from fetal to neonatal life. ${ }^{26,28}$

\section{Leptin in Relation to Reproductive Function}

Leptin seems to be the physiological link between nutritional status and reproductive maturation, interfering with the regulation of adeno- and neuro-hypophysis (growth hormone, hypothalamo-pituitary-thyroid-axis, and hypothalamo-pituitary-adrenal and gonadal axes). ${ }^{14,25,29,30}$ It provides the CNS with information regarding the critical amount of adipose tissue and regulates the reproductive function at the central level via the gonadotropin-releasing hormone and hypothalamic-pituitary-gonadal axis, respectively. 29,30 Furthermore, it has been shown that the secretion of leptin has a pulsatile rhythm, synchronized with that of the luteinizing hormone and estradiol. ${ }^{30}$ Therefore, normal leptin levels are important prerequisites for both the onset of puberty and the maintenance of menstrual cycles and normal reproductive function. $31-35$

\section{Leptin in Relation to Stress}

In animal studies, leptin was found to inhibit responses to stress through enhancement of glucocorticoid receptor expression in CNS and sensitization of the glucocorticoid inhibitory feedback. ${ }^{36,37}$ These mechanisms are already present at birth and provide the newborn with a regulatory mechanism against the variation of adrenal hormones during the critical period of brain development. ${ }^{36,38}$ The role of leptin in human adrenal axis remains controversial, however. While some observational studies reported an inverse association between leptin and adrenocorticotropic hormone levels, other studies comprising subjects with mutations in leptin or the leptin receptor gene reported a normal adrenal function in these people. 39

\section{Leptin in Relation to Brain Development and Psychiatric Outcomes}

The question whether leptin has direct involvement in the development of the brain has been explored in some experimental studies. Leptin is thought to be related to brain development, because leptin receptors are widely expressed 
in the brain and because brain weight as well as brain protein and DNA contents are reduced in adult leptin deficient mice $(o b / o b) .{ }^{40}$ This observation, however, has not been confirmed in the few studies of leptin deficiency in humans. ${ }^{9}$ Another interesting finding of a recent report indicates a possible action of leptin as a cognitive enhancer in the hippocampus and on excitatory synaptic strength. ${ }^{41}$

There is some clinical evidence among adults suffering from major psychiatric diseases that the balance of leptin is disturbed. ${ }^{42}$ It is not clear, however, whether these changes in leptin levels reflect the modification of appetite behavior associated with these disorders or an involvement of leptin in the etiologic pathway of these conditions.

\section{Leptin and Fetal Bone Remodeling}

Leptin controls fetal bone remodeling by enhancing the differentiation of human bone marrow stromal cells to osteoblasts and decreasing bone resorption. ${ }^{43-45}$ Along with the gradual increase in fetal leptin levels with the advancement of gestation, a significant inverse correlation between leptin and the markers of bone resorption has been reported. ${ }^{43}$ It has been proposed that leptin might act, via sympathetic signaling, to modulate the proliferation of osteoblasts, but the exact mechanism of leptin action on bone formation has not been elucidated. ${ }^{45}$

Other findings from animal studies show a positive association between early postnatal leptin levels in piglets and bone mass, along with a negative correlation between leptin and osteocalcine, a peptide that reflects the activity of osteoblasts. ${ }^{46}$ Furthermore, in young $o b / o b$ mice who lack leptin, an elevation of bone size, bone density and mineral content following treatment with leptin has been reported. ${ }^{47-49}$ These findings, namely a strong association between leptin concentrations, body bone mineral contents and estimated bone density, have been recently confirmed in a study including human neonates. ${ }^{23}$

Further studies are needed, however, to explore the function, site and mode of action of leptin on bone formation given the important implications of such a relation. If a direct link between leptin and intrauterine bone formation is clearly demonstrated, it may imply that the risk of osteoporosis in later life may be determined in early life through the regulatory mechanism of leptin, ${ }^{23}$ indicating that interventions for prevention of osteoporosis should start in early life.

\section{Other Roles of Leptin}

Leptin promotes hematopoiesis and lymphopoiesis, stimulating the proliferation and differentiation of yolk sac cells, fetal liver cells and hematopoietic precursors. ${ }^{50-52}$ However, the exact pathways and mechanisms have not yet been determined. At the intestinal level, leptin is implicated in the maturation of intestinal mucosa in the early stages of life and seems to have a protective effect against cell apoptosis and autophagy in the neonatal gut epithelium. ${ }^{53}$ Finally, some animal studies indicate that leptin seems to contribute to pulmonary development in utero, as both the hormone and its receptor are expressed by fibroblasts and pulmonary epithelial cells, including fetal lung type II cells responsible for the secretion of pulmonary surfactant. 54,55

\section{SYNTHESIS AND DYNAMICS OF LEPTIN DURING PREGNANCY}

Leptin seems to be a critical factor for overall fetal development, as well as the evolution and maintenance of the pregnancy, while the regulation and the dynamics of the secretion of the hormone during pregnancy are extremely complex processes. The hormone is produced in both maternal and fetal adipose tissues and in the placenta, while its receptors are expressed in the uterine endometrium and trophoblast and the fetus. ${ }^{56}$

\section{Maternal Leptin Levels}

Circulating maternal leptin levels are substantially elevated during pregnancy due to the gradual increase of the body mass index throughout gestation, whereas the placenta seems to be an independent source of leptin. ${ }^{57,58}$ Increased levels of estradiol stimulate leptin production from adipocytes. The elevated cortisol and insulin levels during pregnancy seem to be involved in this process as well. ${ }^{33}$

The dynamics of leptin follow the overall major metabolic changes during the gestational period, including the anabolic to catabolic shift, and provide further support that leptin is one of the essential factors regulating maternal and fetal energy balance. ${ }^{9,57}$ A two-fold increase in leptin levels is observed in mid-pregnancy, which corresponds to the enhancement of bound leptin levels. ${ }^{57}$ During labor, another significant increase of leptin levels is encountered, which is more pronounced in vaginal compared to Caesarean section delivery. Eventually, maternal leptin levels reach those of a physiological non-pregnant woman 3 to 6 days after delivery. ${ }^{57,59}$

\section{Fetal Leptin Levels}

Fetal adipose tissue is an important source of leptin. Leptin has been identified in fat biopsies obtained from fetuses that died in utero between the $20^{\text {th }}$ and $38^{\text {th }}$ gestational week. ${ }^{60}$ However, the production of the hormone seems to start earlier with lipidogenesis itself, as shown by immunocytochemical staining of developing subcutaneous tissues of human embryos at 6 to 10 weeks of gestation. ${ }^{61}$ Leptin is produced primarily by white adipose tissue cells, while there is some evidence that brown adipose tissue is another source of fetal leptin. ${ }^{26}$

The dynamics of fetal leptin levels follow the evolution of fetal adipose tissue. Thus, the limited development of fetal adipose cells prior to the ages of 32 to 34 weeks is followed by a significant increase of the adipose mass. ${ }^{62,63}$ Similarly, the low fetal leptin levels during the first half of gestation increase dramatically during the last part of the third trimester. ${ }^{63,64}$ The nonsignificant correlation between leptin levels, measured in fetal cord blood between the age of 14 to 
32 weeks, and the pattern of growth emphasizes the importance of the development of adipose tissue in defining leptin levels. ${ }^{64}$ Similar findings were reported in animal studies in which leptin was detected in fetal adipose tissue by the end of the second trimester with a significant increase up to term. ${ }^{26}$

\section{Placental Leptin Levels}

Human placenta expresses the $o b$ gene, and syncytiotrophoblasts have been shown to synthesize leptin. ${ }^{28,65}$ Most of the placental produced leptin is released into maternal circulation and only a small percent is released to the fetus. ${ }^{66}$ The sharp decline in maternal leptin levels following delivery or a spontaneous abortion may, in fact, reflect the cessation of the placental function. ${ }^{57,59}$ Several investigators have emphasized the contribution of the placenta as an additional source of fetal leptin. ${ }^{26}$ In support of this theory is the positive correlation between placental and umbilical cord leptin levels, along with the independence noted between maternal and infant leptin levels. ${ }^{28,67}$

\section{Umbilical Vein and Umbilical Artery Leptin Levels}

Throughout gestation, leptin concentrations are higher in the umbilical vein compared to those in the umbilical artery, and the difference increases significantly during the second half of pregnancy. ${ }^{68}$ The difference persists at delivery, whereas a sharp decline in the leptin levels is observed on the $5^{\text {th }}$ postnatal day. ${ }^{69}$ Notably, umbilical artery leptin seems to have a closer relationship to neonatal anthropometry, while umbilical vein leptin is more closely related to maternal characteristics. ${ }^{70}$ In vaginal deliveries, leptin concentrations in both the umbilical artery and the umbilical vein are increased compared to those in Caesarean sections, indicating an augmented placental leptin release during advanced labor. ${ }^{71}$

\section{FACTORS AFFECTING LEPTIN LEVELS AFTER DELIVERY}

\section{Neonatal Leptin Levels}

Two to three times higher serum leptin levels are observed among infants compared to those among adults. ${ }^{72}$ The origin of newborn leptin from three different sources, the increased adipose leptin mRNA expression in fetal adipose tissue, and the onset of synthesis of leptin prior to the maturation of its receptor may explain this difference. ${ }^{73}$

\section{Sociodemographic Factors}

- Gender. At birth, female newborns have consistently been found to have higher leptin levels than males. ${ }^{74-87}$ Underlying causes might be the differential amount of fat tissue by gender, the role of the variable sex steroid milieus of the newborn and the heavier placental weight associated with female gender. ${ }^{72,88}$

- Family history of obesity. Among other determinants of newborn leptin levels, is that family history of obesity on the paternal side has been associated with higher concentrations of leptin in the umbilical cord. 89

- Ethnicity. Ethnic differences have also been reported, possibly due to variable body composition in some specific population groups. ${ }^{85,90,91}$
Birth Weight

There is converging evidence that a strong correlation between leptin levels and neonatal birth weight exists, ${ }^{72,75,76,81,85-88}$ which can be a reflection of the contribution of body fat mass in determining leptin levels. Thus, intrauterine growth retarded (IUGR), full-term newborns have significantly lower umbilical cord leptin concentrations than appropriate for gestational age neonates at birth. ${ }^{63,92-94}$ IUGR twin newborns also have lower umbilical cord and placental leptin levels compared to their normal size siblings. ${ }^{95}$ Later on, however, children born with IUGR have higher serum leptin levels than children with normal birth weight, which may indicate an adaptative leptin resistance response which is beneficial for the catch-up growth of these children. ${ }^{63}$ Lastly, large for gestational age infants have higher leptin levels at birth than appropriate for gestational age neonates, which are positively correlated with ponderal index and umbilical cord levels of insulin. ${ }^{17,96-100}$

\section{Prematurity}

Compared with healthy full-term babies, preterm neonates have lower leptin levels, which are correlated to their gestational age and birth weight, ${ }^{101-107}$ and increase after the $33^{\text {rd }}$ gestational week as a reflection of respective increases of the adipose tissue. ${ }^{103}$ Moreover, serum leptin seems to be associated with serum insulin and the insulin/glucose ratio, supporting the hypothesis that an 'adipoinsular axis' exists and likely is functional before the $34^{\text {th }}$ gestational week. ${ }^{108}$ The administration of antenatal steroids to advance embryonic maturation has a dose-response relationship with leptin levels at birth. 108

\section{Stress - Septicemia}

An intriguing finding that needs to be confirmed is the increase in leptin levels in neonates with bacterial septicemia, which declines after treatment. This strengthens the role of leptin as a stress-related hormone. ${ }^{109}$

\section{Maternal Factors}

Pathological Conditions

Pathological conditions of mothers are followed by significant changes in leptin levels of their offspring. Children born to mothers who developed gestational diabetes or to mothers with type-1 diabetes mellitus have higher leptin levels at birth compared to those of non-diabetic mothers and are at higher risk for macrosomia. ${ }^{16,65,110-112}$ Involvement of insulin in up-regulating leptin expression in the placenta could be postulated as an underlying mechanism. ${ }^{112}$ Preeclampsia also influences the dynamics of leptin with higher leptin levels reported among neonates born to mothers with this placental insufficiency, possibly due to the adaptative mechanisms determined by hypoxia and subsequent stress. ${ }^{113-116}$ Likewise, leptin levels in neonates suffering from fetal distress and hypercapnia correlate well with $\mathrm{pCO}_{2} \cdot 117$ 
Maternal Smoking During Pregnancy

Smoking during pregnancy is known to be associated with lower birth weight of the offspring, but the findings are unclear with regards to the influence it exerts on leptin levels. It has been suggested that smoking might increase the production of catecholamines in infants and lead to lipolysis, which might be followed by a corresponding decrease in leptin levels. ${ }^{118,119}$ Lower leptin levels were found in some studies, ${ }^{118-120}$ whereas no significant difference of the breast milk leptin levels between smoking and nonsmoking women has been reported. ${ }^{119,121}$

\section{Maternal Nutrition and the Metabolic Status}

Maternal nutrition and metabolic status during pregnancy are of crucial importance. A poor intrauterine milieu determined by maternal nutritional disturbances of placental insufficiency may alter the metabolic balance in the fetus with severe implications in later life. ${ }^{1-4}$ Fetal programming has been recognized as having an essential contribution in defining the adult phenotype ${ }^{1,12,122}$ and brain development is very sensitive to specific nutrient intake which is essential for cell membrane formation and myelinization. ${ }^{123}$

Both maternal overfeeding and fasting during pregnancy perturb glucose equilibrium and have been associated with risk alterations of the offspring with regards to the development of metabolic diseases and other pathological conditions in adulthood. Studies with animal models found a correlation between undernutrition throughout pregnancy and obesity, hyperinsulinemia and hyperleptinemia, ${ }^{124}$ while malnutrition during late gestation or in the first period of extrauterine life resulted in lower leptin levels at the onset of puberty. ${ }^{125}$

Historical observations in humans showed that offspring of women exposed to famine during the Dutch Hunger Winter in their first trimester of pregnancy had increased adiposity, while those exposed during the third trimester of pregnancy had a significantly lower rate of obesity. ${ }^{126}$ Moreover, early gestational famine gave rise to schizophrenia, while later gestational famine was related to a high risk of developing affective disorders requiring hospitalization in adulthood. 127 People exposed to famine in mid and early gestation also had a higher risk for obstructive airway disease. Therefore, it seems that fetal lungs can be permanently affected by nutritional challenges during periods of rapid growth. ${ }^{128}$ While the role of nutrition, regulatory hormones and other factors in the etiology of these pathological conditions has been established overall, it has not yet been clarified whether leptin is an etiological factor itself or a proxy signaling the nutritional imbalances and triggering adaptative reactions.

Apart from the quantity, the quality of diet during pregnancy seems to play a role in defining leptin levels. Maternal deficiency of essential fatty acids during late gestation and lactation has been associated with decreased leptin levels of newborns in animal studies. Thus, a link between maternal dietary content and regulation of the amount of infant adipose tissue and leptin mRNA expression might be present. ${ }^{129}$ Moreover, the umbilical cord concentration of fatty acids seems to determine leptin levels in later life. ${ }^{130}$

\section{Infant Diet}

Different growth patterns in the first year of life are likely to reflect different types of infant diets. Besides the quantitative differences in energy, protein and micronutrients intake between human and formula milk, there are also differences among the growth factors contained, in terms of quality and quantity. Because breast feeding seems to exert a protective effect against obesity in later life, 131,132 it was reasonable to explore the relation between early life diet and leptin levels. The evidence is contradictory. Some studies reported lower leptin levels for breast fed infants compared to children fed with formula milk. ${ }^{72,133}$ It is possible that formula milk may either bring a substantial amount of leptin ${ }^{134}$ or produce some allergic reactions that increase leptin levels. ${ }^{72}$ Other studies found higher leptin levels among breast fed newborns and proposed that this association was due to the acquisition of leptin from breast milk. ${ }^{135-137}$

A correlation between leptin levels in breast milk and patterns of perinatal growth has been suggested by some investigations. Mothers of full-term newborns had double leptin levels in breast milk compared to those of preterm babies, whereas a sharp decline of leptin from colostrum to transitional milk was evident in the former group. ${ }^{138}$ Mothers giving birth to small for gestational age infants had reduced leptin levels in breast milk during the first 15 days after birth compared with appropriate for gestational age and large for gestational age children. ${ }^{139}$ Human milk leptin concentration beyond the neonatal period, however, seems to only correlate well with maternal body mass index but not with the body mass index of these infants. 140,141 Thus, breast milk leptin might have a significant role in growth, appetite and regulation of nutrition in infancy, especially during the early lactation period, and the production of leptin in breast tissue might be regulated according to the needs of the infant. 139

\section{THE ROLE OF EARLY LIFE LEPTIN IN LATER LIFE DEGENERATIVE AND CHRONIC DISEASES}

The thrifty phenotype hypothesis emphasizes the importance of early life environment in programming the susceptibility to chronic diseases in later life. ${ }^{1}$ The programming is an epigenetic phenomena, which means that the fetal genome may suffer alterations to induce adaptative responses during stressful states occurring during the critical period of development. In support of these findings, studies with identical twins have shown that intrauterine environmental factors may be more important in influencing the growth and development of the infant and differentiate the risk of disease in later life than genetic factors. For instance, the twin with a lower weight at birth has an increased risk of developing diabetes mellitus and obesity in later life compared with the other child. ${ }^{142}$ 
Table 1. Factors potentially associated with production and functions of leptin in early life.

\section{Factors}

\begin{tabular}{|c|c|}
\hline $\begin{array}{l}\text { Maternal } \\
\text { Anthropometric }\end{array}$ & Body mass index throughout gestation \\
\hline Pathological & $\begin{array}{l}\text { Gestational diabetes } \\
\text { Type-1 diabetes mellitus } \\
\text { Preeclampsia } \\
\text { Stress, septicemia }\end{array}$ \\
\hline Nutritional & Overfeeding, fasting, poor quality \\
\hline Other & Smoking during pregnancy \\
\hline Placental & $\begin{array}{l}\text { Placental weight } \\
\text { Placental insufficiency }\end{array}$ \\
\hline Neonatal & \\
\hline Anthropometric & Birth weight \\
\hline Socio-demographic & $\begin{array}{l}\text { Gender } \\
\text { Family history of obesity } \\
\text { Ethnicity }\end{array}$ \\
\hline Pathological & Stress, septicemia, hypoxia \\
\hline Nutritional & $\begin{array}{l}\text { Breast feeding } \\
\text { Milk formula }\end{array}$ \\
\hline
\end{tabular}

Both children with low weight at birth and those with high birth weight, as well as neonates suffering from IUGR (a reflection of the consequences of different nutritional or hormonal imbalances and of other pathological events these children encountered during the intrauterine life), have an increased risk of developing obesity, diabetes mellitus and hypertension later in life. ${ }^{2,3,143}$ As indicated, leptin levels are also altered in these children, which points to the role of this hormone in regulating intrauterine growth and development and defining the risk for pathology in later life.

Maternal diseases (e.g., gestational diabetes), as well as placental insufficiency in preeclampsia and fetal pathology, have also been associated with changes in leptin. Moreover, the nutrition of the mother during pregnancy, along with the diet of the infant afterwards, influences leptin levels. Breast feeding seems to provide the newborn with an important source of leptin, essential for adaptation during postnatal life. It is not clear, however, how formula milk may influence the balance of leptin and what health consequences of the changes are induced by artificial feeding.

Leptin signals to the CNS indicates the status of energy resources in terms of availability and promotes specific adaptative reactions, such as setting up a low metabolic waste regimen and influences the overall physiological intrauterine and early life growth and development. ${ }^{10,12,13}$ Later life degenerative outcomes seem to result from the action of environmental factors (e.g., altered nutrition in early life) and the subsequent metabolic and hormonal events they trigger, and leptin is an important mediator of these reactions.
Furthermore, the association of fetal hormone levels with the stem cell potential is an indication that human cancer, in particular breast cancer, may have its origin in the early life time period. ${ }^{7}$ Leptin has been studied in relation to cancer risk and especially with those cancers related to obesity, including breast cancer. Experimental studies have shown that leptin has antiapoptotic effects and promotes cellular growth. However, a direct link between leptin and carcinogenesis could not be demonstrated in clinical studies. ${ }^{144}$

Finally, the exploration of the role of leptin as a bone remodeling regulator and its possible involvement in neuronal and pulmonary development is very important given the implications for prevention.

\section{CONCLUSIONS}

Leptin is a hormone that seems to play a critical role in the regulation of a wide spectrum of functions of organisms, including overall metabolism, immune function, reproductive maturation and bone formation. As indicated, leptin signals to the CNS the availability of energy resources, is likely to trigger adaptative reactions that influence physiological intrauterine and early life growth and development, and appears to contribute to infant adaptations and postnatal growth rates, including neonatal thermogenesis and stress responses.

Birth weight is strongly related to leptin levels, whereas maternal diseases and fetal pathology have also been associated with short-term changes in leptin levels. The nutrition of the mother during pregnancy, along with the diet of the infant afterwards, also influences leptin levels.

Some factors being associated with alterations in leptin levels have also been found to be predictive of adult disease occurrence. Thus, it is reasonable to infer that leptin plays a role in linking early life events and conditions with long-term consequences. The inability to undertake longitudinal studies from early to late life makes it difficult to directly evaluate the existence of such associations. Nevertheless, a role of leptin appears likely, although at this stage, it is difficult to document whether this is a major mediating role or a reflection of other more critical endocrine and growth-related processes.

\section{REFERENCES}

1. Hales CN, Barker DJ. The thrifty phenotype hypothesis. Br Med Bull 2001;60:5-20.

2. Holt RI, Byrne CD. Intrauterine growth, the vascular system, and the metabolic syndrome. Semin Vasc Med 2002;2:33-43.

3. Dunger DB, Ong KK. Endocrine and metabolic consequences of intrauterine growth retardation. Endocrinol Metab Clin North Am 2005;34:597-615, ix.

4. Barker DJ. Fetal origins of coronary heart disease. BMJ 1995;311:171-174.

5. Cooper C, Javaid K, Westlake S, Harvey N, Dennison E. Developmental origins of osteoporotic fracture: the role of maternal vitamin D insufficiency. J Nutr 2005;135:2728S-2734S.

6. Harvey N, Cooper C. The developmental origins of osteoporotic fracture. J Br Menopause Soc 2004;10:14-15, 29. 
7. Trichopoulos D. Hypothesis: does breast cancer originate in utero? Lancet 1990;335:939-940.

8. Zhang Y, Proenca R, Maffei M, Barone M, Leopold L, Friedman JM. Positional cloning of the mouse obese gene and its human homologue. Nature 1994;372:425-432.

9. Christou H, Serdy S, Mantzoros CS. Leptin in relation to growth and developmental processes in the fetus. Semin Reprod Med 2002;20:123-130.

10. El-Haddad MA, Desai M, Gayle D, Ross MG. In utero development of fetal thirst and appetite: potential for programming. J Soc Gynecol Investig 2004;11:123-130.

11. Roberts TJ, Nijland MJ, Caston-Balderrama A, Ross MG Central leptin stimulates ingestive behavior and urine flow in the near term ovine fetus. Horm Metab Res 2001;33:144-150.

12. McMillen IC, Muhlhausler BS, Duffield JA, Yuen BS. Prenatal programming of postnatal obesity: fetal nutrition and the regulation of leptin synthesis and secretion before birth. Proc Nutr Soc 2004;63:405-412.

13. Bouret SG, Draper SJ, Simerly RB. Trophic action of leptin on hypothalamic neurons that regulate feeding. Science 2004;304:108-110.

14. Chan JL, Mantzoros CS. Role of leptin in energy-deprivation states: normal human physiology and clinical implications for hypothalamic amenorrhoea and anorexia nervosa. Lancet 2005;366:74-85

15. Persson B, Westgren M, Celsi G, Nord E, Ortqvist E. Leptin concentrations in cord blood in normal newborn infants and offspring of diabetic mothers. Horm Metab Res 1999;31:467-471.

16. Gross GA, Solenberger T, Philpott T, Holcomb WL Jr, Landt M. Plasma leptin concentrations in newborns of diabetic and nondiabetic mothers. Am J Perinatol 1998;15:243-247.

17. Ben X, Qin Y, Wu S, Zhang W, Cai W. Placental leptin correlates with intrauterine fetal growth and development. Chin Med J (Engl) 2001;114:636-639.

18. Martin-Gronert MS, Ozanne SE. Programming of appetite and type 2 diabetes. Early Hum Dev 2005;81:981-988.

19. Chilliard Y, Bonnet M, Delavaud C, Faulconnier Y, Leroux C, Djiane J, Bocquier F. Leptin in ruminants. Gene expression in adipose tissue and mammary gland, and regulation of plasma concentration. Domest Anim Endocrinol 2001;21:271-295.

20. Hu X, Juneja SC, Maihle NJ, Cleary MP. Leptin - a growth factor in normal and malignant breast cells and for normal mammary gland development. J Natl Cancer Inst 2002;94:1704-1711.

21. O'brien SN, Welter BH, Price TM. Presence of leptin in breast cell lines and breast tumors. Biochem Biophys Res Commun 1999;259:695-698.

22. Yarbrough DE, Barrett-Connor E, Morton DJ. Birth weight as a predictor of adult bone mass in postmenopausal women: the Rancho Bernardo Study. Osteoporos Int 2000;11:626-630.

23. Javaid MK, Godfrey KM, Taylor P, Robinson SM, Crozier SR, Dennison EM, Robinson JS, Breier BR, Arden NK, Cooper C. Umbilical cord leptin predicts neonatal bone mass. Calcif Tissue Int 2005;76:341-347.

24. Huang L, Li C. Leptin: a multifunctional hormone. Cell Res 2000;10:81-92.

25. Meier U, Gressner AM. Endocrine regulation of energy metabolism: review of pathobiochemical and clinical chemical aspects of leptin, ghrelin, adiponectin, and resistin. Clin Chem 2004;50:1511-1525.

26. Mostyn A, Keisler DH, Webb R, Stephenson T, Symonds ME. The role of leptin in the transition from fetus to neonate. Proc Nutr Soc 2001;60:187-194.

27. Hassink SG, de Lancey E, Sheslow DV, Smith-Kirwin SM, O'Connor DM, Considine RV, Opentanova I, Dostal K, Spear ML, Leef K, Ash M, Spitzer AR, Funanage VL. Placental leptin: an important new growth factor in intrauterine and neonatal development? Pediatrics 1997;100:E1.
28. Mostyn A, Pearce S, Stephenson T, Symonds ME. Hormonal and nutritional regulation of adipose tissue mitochondrial development and function in the newborn. Exp Clin Endocrinol Diabetes 2004;112:2-9.

29. Casanueva FF, Dieguez C. Neuroendocrine regulation and actions of leptin. Front Neuroendocrinol 1999;20:317-363.

30. Licinio J, Negrao AB, Mantzoros C, Kaklamani V, Wong ML, Bongiorno PB, Mulla A, Cearnal L, Veldhuis JD, Flier JS, McCann SM, Gold PW. Synchronicity of frequently sampled, 24-h concentrations of circulating leptin, luteinizing hormone, and estradiol in healthy women. Proc Natl Acad Sci U S A 1998;95:2541-2546.

31. Cunningham MJ, Clifton DK, Steiner RA. Leptin's actions on the reproductive axis: perspectives and mechanisms. Biol Reprod 1999;60:216-222.

32. Messinis IE, Milingos SD. Leptin in human reproduction. Hum Reprod Update 1999;5:52-63.

33. Mantzoros CS. Role of leptin in reproduction. Ann N Y Acad Sci 2000;900:174-183.

34. Mantzoros CS, Flier JS, Rogol AD. A longitudinal assessment of hormonal and physical alterations during normal puberty in boys. V. Rising leptin levels may signal the onset of puberty. J Clin Endocrinol Metab 1997;82:1066-1070.

35. Baldelli R, Dieguez C, Casanueva FF. The role of leptin in reproduction: experimental and clinical aspects. Ann Med 2002;34:5-18.

36. Walker CD, Salzmann C, Long H, Otis M, Roberge C, Gallo-Payet N. Direct inhibitory effects of leptin on the neonatal adrenal and potential consequences for brain glucocorticoid feedback. Endocr Res 2004;30:837-844.

37. Proulx K, Clavel S, Nault G, Richard D, Walker CD. High neonatal leptin exposure enhances brain GR expression and feedback efficacy on the adrenocortical axis of developing rats. Endocrinology 2001;142:4607-4616.

38. Oates M, Woodside B, Walker CD. Chronic leptin administration in developing rats reduces stress responsiveness partly through changes in maternal behavior. Horm Behav 2000;37:366-376.

39. Kelesidis T, Mantzoros CS. The emerging role of leptin in humans. Pediatr Endocrinol Rev 2006;3:239-248.

40. Udagawa J, Nimura M, Kagohashi Y, Otani H. Leptin deficiency causes pycnotic change in fetal cingulate cortical cells. Congenit Anom (Kyoto) 2006;46:16-20.

41. Harvey J, Shanley LJ, O’Malley D, Irving AJ. Leptin: a potential cognitive enhancer? Biochem Soc Trans 2005;33:1029-1032.

42. Jow GM, Yang TT, Chen CL. Leptin and cholesterol levels are low in major depressive disorder, but high in schizophrenia. J Affect Disord 2006;90:21-27.

43. Ogueh O, Sooranna S, Nicolaides KH, Johnson MR. The relationship between leptin concentration and bone metabolism in the human fetus. J Clin Endocrinol Metab 2000;85:1997-1999.

44. Elefteriou F, Ahn JD, Takeda S, Starbuck M, Yang X, Liu X, Kondo H, Richards WG, Bannon TW, Noda M, Clement K, Vaisse C, Karsenty G. Leptin regulation of bone resorption by the sympathetic nervous system and CART. Nature 2005;434:514-520.

45. Fu L, Patel MS, Bradley A, Wagner EF, Karsenty G. The molecular clock mediates leptin-regulated bone formation. Cell 2005;122:803-815.

46. Weiler HA, Kovacs H, Murdock C, Adolphe J, Fitzpatrick-Wong $\mathrm{S}$. Leptin predicts bone and fat mass after accounting for the effects of diet and glucocorticoid treatment in piglets. Exp Biol Med (Maywood) 2002;227:639-644.

47. Steppan CM, Crawford DT, Chidsey-Frink KL, Ke H, Swick AG. Leptin is a potent stimulator of bone growth in ob/ob mice. Regul Pept 2000;92:73-78. 
48. Nelson-Dooley C, Della-Fera MA, Hamrick M, Baile CA. Novel treatments for obesity and osteoporosis: targeting apoptotic pathways in adipocytes. Curr Med Chem 2005; $12: 2215-2225$.

49. Hamrick MW, Della-Fera MA, Choi YH, Pennington C, Hartzell D, Baile CA. Leptin treatment induces loss of bone marrow adipocytes and increases bone formation in leptin-deficient ob/ob mice. J Bone Miner Res 2005;20:994-1001.

50. Bennett BD, Solar GP, Yuan JQ, Mathias J, Thomas GR, Matthews W. A role for leptin and its cognate receptor in hematopoiesis. Curr Biol 1996;6:1170-1180.

51. Mikhail AA, Beck EX, Shafer A, Barut B, Gbur JS, Zupancic TJ, Schweitzer AC, Cioffi JA, Lacaud G, Ouyang B, Keller G, Snodgrass HR. Leptin stimulates fetal and adult erythroid and myeloid development. Blood 1997;89:1507-1512.

52. Mantzoros CS, Moschos SJ. Leptin: in search of role(s) in human physiology and pathophysiology. Clin Endocrinol (Oxf) 1998;49:551-567.

53. Godlewski MM, Slupecka M, Wolinski J, Skrzypek T, Skrzypek H, Motyl T, Zabielski R. Into the unknown - the death pathways in the neonatal gut epithelium. J Physiol Pharmacol 2005;56:7-24.

54. Torday JS, Sun H, Wang L, Torres E, Sunday ME, Rubin LP. Leptin mediates the parathyroid hormone-related protein paracrine stimulation of fetal lung maturation. Am J Physiol Lung Cell Mol Physiol 2002;282:L405-L410.

55. Henson MC, Swan KF, Edwards DE, Hoyle GW, Purcell J, Castracane VD. Leptin receptor expression in fetal lung increases in late gestation in the baboon: a model for human pregnancy. Reproduction 2004;127:87-94.

56. Henson MC, Castracane VD. Leptin in pregnancy: an update. Biol Reprod 2006;74:218-229.

57. Lewandowski K, Horn R, O'Callaghan CJ, Dunlop D, Medley GF, O'Hare P, Brabant G. Free leptin, bound leptin, and soluble leptin receptor in normal and diabetic pregnancies. J Clin Endocrinol Metab 1999;84:300-306.

58. Yang MJ. Interrelationships of maternal serum leptin, body mass index and gestational age. J Chin Med Assoc 2005;68:452-457.

59. Nuamah MA, Yura S, Sagawa N, Itoh H, Mise H, Korita D, Kakui K, Takemura M, Ogawa Y, Nakao K, Fujii S. Significant increase in maternal plasma leptin concentration in induced delivery: a possible contribution of pro-inflammatory cytokines to placental leptin secretion. Endocr J 2004;51:177-187.

60. Lepercq J, Challier JC, Guerre-Millo M, Cauzac M, Vidal H, Hauguel-de Mouzon S. Prenatal leptin production: evidence that fetal adipose tissue produces leptin. J Clin Endocrinol Metab 2001;86:2409-2413.

61. Atanassova P, Popova L. Leptin expression during the differentiation of subcutaneous adipose cells of human embryos in situ. Cells Tissues Organs 2000;166:15-19.

62. Widdowson EM, Southgate DAT, Hey EN. Body composition of the fetus and infant. In: Visser HKA, ed. Nutrition and metabolism of the fetus and infant. London: Martinus Nijhoff; 1979. 169-177.

63. Jaquet D, Leger J, Levy-Marchal C, Oury JF, Czernichow P. Ontogeny of leptin in human fetuses and newborns: effect of intrauterine growth retardation on serum leptin concentrations. J Clin Endocrinol Metab 1998;83:1243-1246.

64. Geary M, Herschkovitz R, Pringle PJ, Rodeck CH, Hindmarsh PC. Ontogeny of serum leptin concentrations in the human. Clin Endocrinol (Oxf) 1999;51:189-192.

65. Senaris R, Garcia-Caballero T, Casabiell X, Gallego R, Castro R, Considine RV, Dieguez C, Casanueva FF. Synthesis of leptin in human placenta. Endocrinology 1997;138:4501-4504.

66. Linnemann K, Malek A, Sager R, Blum WF, Schneider H, Fusch C. Leptin production and release in the dually in vitro perfused human placenta. J Clin Endocrinol Metab 2000;85:4298-4301.
67. Lea RG, Howe D, Hannah LT, Bonneau O, Hunter L, Hoggard N. Placental leptin in normal, diabetic and fetal growth-retarded pregnancies. Mol Hum Reprod 2000;6:763-769.

68. Vitoratos N, Chrystodoulacos G, Salamalekis E, Kassanos D, Kouskouni E, Creatsas G. Fetoplacental leptin levels and their relation to birth weight and insulin in gestational diabetic pregnant women. J Obstet Gynaecol 2002;22:29-33.

69. Yura S, Sagawa N, Mise H, Mori T, Masuzaki H, Ogawa Y, Nakao K. A positive umbilical venous-arterial difference of leptin level and its rapid decline after birth. Am J Obstet Gynecol 1998;178:926-930.

70. Yang MJ, Liu RS, Hung JH. Leptin concentrations in the umbilical vein and artery. Relationship to maternal and neonatal anthropometry. J Reprod Med 2002;47:645-650.

71. Yoshimitsu N, Douchi T, Kamio M, Nagata Y. Differences in umbilical venous and arterial leptin levels by mode of delivery. Obstet Gynecol 2000;96:342-345.

72. Petridou E, Mantzoros CS, Belechri M, Skalkidou A, Dessypris N, Papathoma E, Salvanos H, Lee JH, Kedikoglou S, Chrousos G, Trichopoulos D. Neonatal leptin levels are strongly associated with female gender, birth length, IGF-I levels and formula feeding. Clin Endocrinol (Oxf) 2005;62:366-371

73. Kratzsch J, Schubring C, Stitzel B, Bottner A, Berthold A, Thiery J, Kiess W. Inverse changes in the serum levels of the soluble leptin receptor and leptin in neonates: relations to anthropometric data. J Clin Endocrinol Metab 2005;90:2212-2217.

74. Laml T, Preyer O, Schulz-Lobmeyr I, Ruecklinger E, Hartmann BW, Wagenbichler P. Umbilical venous leptin concentration and gender in newborns. J Soc Gynecol Investig 2001;8:94-97.

75. Matsuda J, Yokota I, Iida M, Murakami T, Naito E, Ito M, Shima K, Kuroda Y. Serum leptin concentration in cord blood: relationship to birth weight and gender. J Clin Endocrinol Metab 1997;82:1642-1644.

76. Yang SW, Kim SY. The relationship of the levels of leptin, insulin-like growth factor-I and insulin in cord blood with birth size, ponderal index, and gender difference. J Pediatr Endocrinol Metab 2000;13:289-296.

77. Babay ZA, Warsy AS, El-Hazmi MA, Addar MH. Leptin level in pregnant mothers at term and cord blood and the effect of newborns gender. Saudi Med J 2004;25:212-214.

78. Pardo IM, Geloneze B, Tambascia MA, Barros-Filho AA. Hyperadiponectinemia in newborns: relationship with leptin levels and birth weight. Obes Res 2004;12:521-524.

79. Pulzer F, Haase U, Knupfer M, Kratzsch J, Richter V, Rassoul F, Kiess W, Keller E. Serum leptin in formerly small-for-gestational-age children during adolescence: relationship to gender, puberty, body composition, insulin sensitivity, creatinine, and serum uric acid. Metabolism 2001;50:1141-1146.

80. Maffeis C, Moghetti P, Vettor R, Lombardi AM, Vecchini S, Tato L. Leptin concentration in newborns' cord blood: relationship to gender and growth-regulating hormones. Int J Obes Relat Metab Disord 1999;23:943-947.

81. Vatten LJ, Nilsen ST, Odegard RA, Romundstad PR, Austgulen R. Insulin-like growth factor I and leptin in umbilical cord plasma and infant birth size at term. Pediatrics 2002;109:1131-1135.

82. Tome MA, Lage M, Camina JP, Garcia-Mayor RV, Dieguez C, Casanueva FF. Sex-based differences in serum leptin concentrations from umbilical cord blood at delivery. Eur J Endocrinol 1997; 137:655-658.

83. Bellone S, Rapa A, Petri A, Zavallone A, Strigini L, Chiorboli E, Ciardi L, Aguzzi A, Bona G. Leptin levels as function of age, gender, auxological and hormonal parameters in 202 healthy neonates at birth and during the first month of life. J Endocrinol Invest 2004;27:18-23. 
84. Okereke NC, Uvena-Celebrezze J, Hutson-Presley L, Amini $\mathrm{SB}$, Catalano PM. The effect of gender and gestational diabetes mellitus on cord leptin concentration. Am J Obstet Gynecol 2002;187:798-803.

85. Yeung LP, Wong AC, Wang X, Birmingham CL, Lewicka S, Chanoine JP. Different relationship between anthropometric markers and umbilical cord plasma leptin in Asian and Caucasian neonates. Pediatr Res 2003;53:1019-1024.

86. Tsai PJ, Yu CH, Hsu SP, Lee YH, Chiou CH, Hsu YW, Ho SC, $\mathrm{Chu} \mathrm{CH}$. Cord plasma concentrations of adiponectin and leptin in healthy term neonates: positive correlation with birthweight and neonatal adiposity. Clin Endocrinol (Oxf) 2004;61:88-93.

87. Saad MF, Damani S, Gingerich RL, Riad-Gabriel MG, Khan A, Boyadjian R, Jinagouda SD, el-Tawil K, Rude RK, Kamdar V. Sexual dimorphism in plasma leptin concentration. J Clin Endocrinol Metab 1997;82:579-584.

88. Watanobe H, Habu S. Manipulation of neonatal gonadal steroid milieu and leptin secretion in later life in male and female rats. Regul Pept 2003;110:219-224.

89. Tarquini B, Tarquini R, Perfetto F, Cornelissen G, Halberg F. Genetic and environmental influences on human cord blood leptin concentration. Pediatrics 1999;103:998-1006.

90. Simmons D, Breier BH. Fetal overnutrition in polynesian pregnancies and in gestational diabetes may lead to dysregulation of the adipoinsular axis in offspring. Diabetes Care 2002;25:1539-1544.

91. Yajnik CS, Lubree HG, Rege SS, Naik SS, Deshpande JA, Deshpande SS, Joglekar CV, Yudkin JS. Adiposity and hyperinsulinemia in Indians are present at birth. J Clin Endocrinol Metab 2002;87:5575-5580.

92. Yildiz L, Avci B, Ingec M. Umbilical cord and maternal blood leptin concentrations in intrauterine growth retardation. Clin Chem Lab Med 2002;40:1114-1117.

93. Pighetti M, Tommaselli GA, D'Elia A, Di Carlo C, Mariano A, Di Carlo A, Nappi C. Maternal serum and umbilical cord blood leptin concentrations with fetal growth restriction. Obstet Gynecol 2003;102:535-543.

94. Cetin I, Morpurgo PS, Radaelli T, Taricco E, Cortelazzi D, Bellotti M, Pardi G, Beck-Peccoz P. Fetal plasma leptin concentrations: relationship with different intrauterine growth patterns from 19 weeks to term. Pediatr Res 2000;48:646-651.

95. Sooranna SR, Ward S, Bajoria R. Fetal leptin influences birth weight in twins with discordant growth. Pediatr Res 2001;49:667-672.

96. Mazaki-Tovi S, Kanety H, Pariente C, Hemi R, Schiff E, Sivan E. Cord blood adiponectin in large-for-gestational age newborns. Am J Obstet Gynecol 2005;193:1238-1242.

97. Christou H, Connors JM, Ziotopoulou M, Hatzidakis V, Papathanassoglou E, Ringer SA, Mantzoros CS. Cord blood leptin and insulin-like growth factor levels are independent predictors of fetal growth. J Clin Endocrinol Metab 2001;86:935-938.

98. Wiznitzer A, Furman B, Zuili I, Shany S, Reece EA, Mazor M. Cord leptin level and fetal macrosomia. Obstet Gynecol 2000;96:707-713.

99. Wolf HJ, Ebenbichler CF, Huter O, Bodner J, Lechleitner M, Foger B, Patsch JR, Desoye G. Fetal leptin and insulin levels only correlate inlarge-for-gestational age infants. Eur J Endocrinol 2000;142:623-629.

100. Varvarigou A, Mantzoros CS, Beratis NG. Cord blood leptin concentrations in relation to intrauterine growth. Clin Endocrinol (Oxf) 1999;50:177-183.

101. Haugen F, Ranheim T, Harsem NK, Lips E, Staff AC, Drevon CA. Increased plasma levels of adipokines in preeclampsia: relationship to placenta and adipose tissue gene expression. Am J Physiol Endocrinol Metab 2006;290:E326-E333.
102. Naruse K, Yamasaki M, Umekage H, Sado T, Sakamoto Y, Morikawa H. Peripheral blood concentrations of adiponectin, an adipocyte-specific plasma protein, in normal pregnancy and preeclampsia. J Reprod Immunol 2005;65:65-75.

103. Takahashi Y, Yokoyama Y, Kawabata I, Iwasa S, Tamaya T. Leptin as an acute stress-related hormone in the fetoplacental circulation. Obstet Gynecol 2002;100:655-658.

104. Gomez L, Carrascosa A, Yeste D, Potau N, Rique S, Ruiz-Cuevas P, Almar J. Leptin values in placental cord blood of human newborns with normal intrauterine growth after 30-42 weeks of gestation. Horm Res 1999;51:10-14.

105. Matsuda J, Yokota I, Iida M, Murakami T, Yamada M, Saijo T, Naito E, Ito M, Shima K, Kuroda Y. Dynamic changes in serum leptin concentrations during the fetal and neonatal periods. Pediatr Res 1999;45:71-75.

106. Stoll-Becker S, Kreuder J, Reiss I, Etspuler J, Blum WF, Gortner L. Influence of gestational age and intrauterine growth on leptin concentrations in venous cord blood of human newborns. Klin Padiatr 2003;215:3-8.

107. Lindsay RS, Hamilton BA, Calder AA, Johnstone FD, Walker JD; Scottish Multicentre Study of Diabetes in Pregnancy. The relation of insulin, leptin and IGF-1 to birth weight in offspring of women with type 1 diabetes. Clin Endocrinol (Oxf) 2004;61:353-359.

108. Orbak Z, Coker M, Darcan S, Goksen D. Association between serum leptin and anthropometric parameters at birth and at 15 th day of life in infants born asymmetrically small for gestational age. J Pediatr Endocrinol Metab 2001;14:185-192.

109. Hytinantti T, Koistinen HA, Koivisto VA, Karonen SL, Andersson S. Changes in leptin concentration during the early postnatal period: adjustment to extrauterine life? Pediatr Res 1999;45:197-201.

110. Tapanainen P, Leinonen E, Ruokonen A, Knip M. Leptin concentrations are elevated in newborn infants of diabetic mothers. Horm Res 2001;55:185-190.

111. Persson B, Westgren M, Celsi G, Nord E, Ortqvist E. Leptin concentrations in cord blood in normal newborn infants and offspring of diabetic mothers. Horm Metab Res 1999;31:467-471.

112. Lepercq J, Cauzac M, Lahlou N, Timsit J, Girard J, Auwerx J, Hauguel-de Mouzon S. Overexpression of placental leptin in diabetic pregnancy: a critical role for insulin. Diabetes 1998;47:847-850.

113. Hytinantti T, Koistinen HA, Koivisto VA, Karonen SL, Rutanen EM, Andersson S. Increased leptin concentration in preterm infants of pre-eclamptic mothers. Arch Dis Child Fetal Neonatal Ed 2000;83:F13-F16.

114. Diaz E, Halhali A, Luna C, Diaz L, Avila E, Larrea F. Newborn birth weight correlates with placental zinc, umbilical insulin-like growth factor I, and leptin levels in preeclampsia. Arch Med Res 2002;33:40-47.

115. Shekhawat PS, Garland JS, Alex C, Sasidharan P, Mick G, McCormick KL. Cord blood and postnatal serum leptin and its relationship to steroid use and growth in sick preterm infants. J Pediatr Endocrinol Metab 2000;13:1571-1576.

116. Ng PC, Lam CW, Lee CH, Wong GW, Fok TF, Wong E, Chan $\mathrm{IH}, \mathrm{Ma} \mathrm{KC}$. Changes of leptin and metabolic hormones in preterm infants: a longitudinal study in early postnatal life. Clin Endocrinol (Oxf) 2001;54:673-680.

117. Orbak Z, Ertekin V, Akcay F, Ozkan B, Ors R. Serum leptin levels in neonatal bacterial septicemia. J Pediatr Endocrinol Metab 2003;16:727-731.

118. Mantzoros CS, Varvarigou A, Kaklamani VG, Beratis NG, Flier JS. Effect of birth weight and maternal smoking on cord blood leptin concentrations of full-term and preterm newborns. J Clin Endocrinol Metab 1997;82:2856-2861.

119. Ozkan B, Ermis B, Tastekin A, Doneray H, Yildirim A, Ors. Effect of smoking on neonatal and maternal serum and breast milk leptin levels. Endocr Res 2005;31:177-183. 
120. Pardo IM, Geloneze B, Tambascia MA, Barros-Filho AA. Does maternal smoking influence leptin levels in term, appropriate-for-gestational-age newborns? J Matern Fetal Neonatal Med 2004;15:408-410.

121. Zanardo V, Nicolussi S, Cavallin S, Trevisanuto D, Barbato A, Faggian D, Favaro F, Plebani M. Effect of maternal smoking on breast milk interleukin-1alpha, beta-endorphin, and leptin concentrations and leptin concentrations. Environ Health Perspect 2005;113:1410-1413.

122. Wyrwoll CS, Mark PJ, Mori TA, Puddey IB, Waddell BJ. Prevention of programmed hyperleptinemia and hypertension by postnatal dietary omega-3 fatty acids. Endocrinology 2006;147:599-606

123. Walker CD. Nutritional aspects modulating brain development and the responses to stress in early neonatal life. Prog Neuropsychopharmacol Biol Psychiatry 2005;29:1249-1263.

124. Yura S, Itoh H, Sagawa N, Yamamoto H, Masuzaki H, Nakao K, Kawamura M, Takemura M, Kakui K, Ogawa Y, Fujii S. Role of premature leptin surge in obesity resulting from intrauterine undernutrition. Cell Metab 2005;1:371-378.

125. Engelbregt MJ, van Weissenbruch MM, Popp-Snijders C, Lips P, Delemarre-van de Waal HA. Body mass index, body composition, and leptin at onset of puberty in male and female rats after intrauterine growth retardation and after early postnatal food restriction. Pediatr Res 2001;50:474-478.

126. Jackson AA, Langley-Evans SC, McCarthy HD. Nutritional influences in early life upon obesity and body proportions. Ciba Found Symp 1996;201:118-129.

127. Brown AS, van Os J, Driessens C, Hoek HW, Susser ES. Further evidence of relation between prenatal famine and major affective disorder. Am J Psychiatry 2000;157:190-195.

128. Lopuhaa CE, Roseboom TJ, Osmond C, Barker DJ, Ravelli AC, Bleker OP, van der Zee JS, van der Meulen JH. Atopy, lung function, and obstructive airways disease after prenatal exposure to famine. Thorax 2000;55:555-561.

129. Korotkova M, Gabrielsson B, Hanson LA, Strandvik B. Maternal dietary intake of essential fatty acids affects adipose tissue growth and leptin mRNA expression in suckling rat pups. Pediatr Res 2002;52:78-84.

130. Rump P, Popp-Snijders C, Heine RJ, Hornstra G. Components of the insulin resistance syndrome in seven-year-old children: relations with birth weight and the polyunsaturated fatty acid content of umbilical cord plasma phospholipids. Diabetologia 2002;45:349-355.

131. Locke R. Preventing obesity: the breast milk-leptin connection. Acta Paediatr 2002;91:891-894.

132. Novotny R, Daida YG, Grove JS, Acharya S, Vogt TM. Formula feeding in infancy is associated with adolescent body fat and earlier menarche. Cell Mol Biol (Noisy-le-grand) 2003;49:1289-1293.

133. Butte NF, Wong WW, Hopkinson JM, Smith EO, Ellis KJ. Infant feeding mode affects early growth and body composition. Pediatrics 2000;106:1355-1366.

134. Lage M, Baldelli R, Camina JP, Rodriguez-Garci J, Penalva A, Dieguez C, Casanueva FF. Presence of bovine leptin in edible commercial milk and infant formula. J Endocrinol Invest 2002;25:670-674.

135. Savino F, Nanni GE, Maccario S, Costamagna M, Oggero R, Silvestro L. Breast-fed infants have higher leptin values than formula-fed infants in the first four months of life. J Pediatr Endocrinol Metab 2004;17:1527-1532.

136. Lonnerdal B, Havel PJ. Serum leptin concentrations in infants: effects of diet, sex, and adiposity. Am J Clin Nutr 2000;72:484-489.

137. Lyle RE, Kincaid SC, Bryant JC, Prince AM, McGehee RE Jr. Human milk contains detectable levels of immunoreactive leptin. Adv Exp Med Biol 2001;501:87-92.
138. Bielicki J, Huch R, von Mandach U. Time-course of leptin levels in term and preterm human milk. Eur J Endocrinol 2004; 151:271-276.

139. Dundar NO, Anal O, Dundar B, Ozkan H, Caliskan S, Buyukgebiz A. Longitudinal investigation of the relationship between breast milk leptin levels and growth in breast-fed infants. J Pediatr Endocrinol Metab 2005;18:181-187.

140. Ucar B, Kirel B, Bor O, Kilic FS, Dogruel N, Aydogdu SD, Tekin N. Breast milk leptin concentrations in initial and terminal milk samples: relationships to maternal and infant plasma leptin concentrations, adiposity, serum glucose, insulin, lipid and lipoprotein levels. J Pediatr Endocrinol Metab 2000;13:149-156.

141. Uysal FK, Onal EE, Aral YZ, Adam B, Dilmen U, Ardicolu Y. Breast milk leptin: its relationship to maternal and infant adiposity. Clin Nutr 2002;21:157-160.

142. Iliadou A, Cnattingius S, Lichtenstein P. Low birth weight and type 2 diabetes: a study on 11162 Swedish twins. Int J Epidemiol 2004;33:948-953.

143. Barker DJ. The developmental origins of chronic adult disease. Acta Paediatr Suppl 2004;93:26-33.

144. Alexe DM, Petridou E. Leptin and cancer. In: Castracane D and Henson MC, eds. Endocrine update. New York, NY: Springer; 2006.

\section{AUTHOR AFFILIATIONS}

Delia-Marina Alexe, MD

Department of Hygiene and Epidemiology

Athens University School of Medicine

Athens, Greece

Garyfallia Syridou, $M D$

Department of Hygiene and Epidemiology

Athens University School of Medicine

Athens, Greece

Eleni Th. Petridou, MD, MPH

Department of Hygiene and Epidemiology

Athens University School of Medicine

Athens, Greece 